\title{
掘さく作業計画に関する研究
}

\author{
田中彰 一*
}

(昭和 43 年 8 月 2 日受理)

\section{A Study on the Planning of Drilling Operation}

by

Shoichi TANAKA

\begin{abstract}
As a result of laboratory experiments and analyses of field data, four equations of bit performance were suggested as in the previous papers, i.e., euqations of performance line, penetration rate at the separation point, relative penetration rate and bit life. In this paper methods obtaining such factors as penetration rate, drilling time and length of a bit, and optimum combination of bit weight and rotary speed, are generally discussed by using aforemantioned equatious with the efiect of hydraulics included. An impact force developed at a bit nozzle is governed by quantity of drill collars to be used; penetration rate, rate of drilling operation, and drilling time and length of a bit may be affected by quantity of drill collars to be used. There is the optimum bit weight which gives the maximum penetration rate under a given rotary speed, and, in the most case, the rate of drilling operation also attains at the maximum value under the same conditions. As an example of application of it to actual driling practices, influences on the penetration rate of pump operations, i.e., single pump operation and parallel operation of two pumps, and also quantity of drill collars are examined on the basis of analyses of field date.
\end{abstract}

掘進率研究の目的の 1 つは，各地域ごとに，あるいは 各地層ごとに，適したビット荷重やビット回転数を求め ることである。これらの諸值を求める方法としては Gelle ら (1963) の方法をはじ,多くの研究が発表されており, わが国でも採用されている。わが国の現場記録を調べる と，泥水循環の作用が不十なところで掘さくが行なわれ ていることが多い(田中, 1968-b)。このような状態では， 最適なビット荷重打よびビット回䎐数はポンプの能力あ るいは使用条件を考虑して決めることが必要である。ポ ンプ能力を考應した方法としてはEdwards の hydraulics test（1964）がある。泥水㼙環と掘進率の関係を数量的 に表わすうj法については，前 2 論文（田中，1968-a，b) で論じた。そこで提案したす法により，ポンプ能力を考 虑しながら最適掘さく作業計画をたてる方法を考察す る。

\footnotetext{
* 東京大学工学部資源開発工学科
}

\section{I 掘進率関係諸式の一般論}

地層の性質・ビット型式・泥水の性質などが与えられ ているとき，掘進率に影響を与えるおもな要素はビット 荷重・ビット回転数・泥水循環の 2 つであり，これらの 組み合せにより掘進率およびビット使用時間あるいは使 用長さが変化する。これらの諸值を推定するために必要 な式としては次のものがある。

作用線の式

$$
R_{0}=m N\left(W-W_{c}\right) / D
$$

分岐点掘進摔の式

$$
R_{b}=a+b\left(D_{0} / D\right)^{2} M
$$

相対掘進率の式

$$
R / R_{0}=\left(\frac{c}{\frac{W-W_{c}}{W_{b}-W_{c}}+d}\right)^{e}
$$

ビット夷:命の式 


$$
N T=\frac{f}{\left(D_{0} W / D\right)^{g}}
$$

ここで

$R_{0}=$ 泥水循環の作用が十分なところでの掘進率

$\mathrm{m} / \mathrm{hr}$

$R=$ 泥水循環の作用が不十分なところでの掘進率 $\mathrm{m} / \mathrm{hr}$

\begin{tabular}{|c|c|}
\hline$R_{b}=$ 分岐点掘進率 & $\mathrm{m} / \mathrm{hr}$ \\
\hline$W=$ ビット荷重 & $\mathrm{t}$ \\
\hline$W_{b}=$ 分岐点荷重 & $\mathrm{t}$ \\
\hline$W_{c}=$ 交点荷重 & $\mathrm{t}$ \\
\hline$N=$ ビット回䎐数 & $\mathrm{rpm}$ \\
\hline$M=$ 衝撃力 & $\mathrm{kg} / \mathrm{g} \cdot \mathrm{cm}^{-3}$; \\
\hline$T=$ ビット使用時間 & $\mathrm{hr}$ \\
\hline$D=$ ビット径 & $\mathrm{cm}$ \\
\hline$D_{0}=$ 基準ビット径 & $\mathrm{cm}$ \\
\hline
\end{tabular}

上記の各式は前論文 (田中，1968-b) に記したように， 現場記録の解析により求めることができる。以下地層の 性質は一様で変化しない，またビット摩耗の影響は考慮 しないとして考察を行なう。

\section{1. 掘 進 率}

泥水循環の作用が十分なときの掘進率は (1) 式で計 算できる。実際の掘さくに执いてはポンプの能力に限界 があるので, 掘進率が大きくなると掘首の除去がまにあ わなくなり, 掘進率は作用線より分岐してくる。この分 岐点にあたる掘進率（分岐点掘進率）は泥水循環の作用 が十分行なわれている状態で達しうる最高の掘進率であ る。泥水循環の作用が十分行なわれているときは, 掘進 率はポンプの能力には無関係である。分岐点掘進率は (2)式で表わされ，ビットノズルに抢ける衝撃力に関係 する，すなわち，ポンプが大型で大きな衝撃力を出せる ときは分岐点掘進率は大きくなり，(1)式で表わせる範 囲が大きくなる。分岐点荷重は（1）式と（2）式を組 み合せて得られる。

$$
\text { 分岐点荷重 } W_{b}=W_{c}+D R_{b} / N
$$

分岐点掘進率はビット回転数に無関係であるが，分岐 点荷重はビット回転数が大きい㤝ど小さい。

作用線から分岐後もビット荷重を增加すると掘進率は 增加するが, その増加の割合は徐々に低下し, やがて掘 進率はあるビット荷重で最大值に達し, それ以上ビット 荷重をかけるとかって掘進率は減少する。作用線から分 岐後の掘進率とビット荷重の関係は（3）式で表わされ る。相対掘進率の式とし前論文（田中，1968-a）に記し た軟層用ビットに対する次式を用いると，

相対掘進率の式（軟層用）

$$
\frac{R}{R_{0}}=\left(\frac{13}{\frac{W-W_{c}}{W_{b}-W_{c}}+12}\right)^{3.85}
$$

ある一定の衝撃力で掘さくするとき達しうる最大掘進 率 $R_{m}$ と，そのときのビット荷重 $W_{m}$ は次のようにな る。

$$
\begin{array}{ll}
\text { 最大掘進率 } & R_{m}=1.9 R_{b} \\
\text { 相対最大荷重 } & \frac{W_{m}-W_{c}}{W_{b}-W_{c}}=4.2
\end{array}
$$

最大掘進率は分岐掘進率の 1.9 倍である。分岐点掘進 率はビット回転数に関係なく，衝撃力のみに関係するか ら，最大掘進率衝撃力のみに関係する。最大荷重の相 対值は 4.2 であり, 分岐点荷重はビット回転数が大きい 㴗ど小さいから，最大荷重もビット回転数が大きい注ど 小さい。衝撃力一定のとき，大きビット回転数で掘さく すると,ビット荷重の小さいところで最大掘進率に達し, 小さなビット回転数で掘さくすると，ビット荷重の大き いところで最大掘進率に達し, 両者の最大掘進率は等し w。

ビット荷重と衝撃力が与えられたとき, 掘進率が最大 掘進率になるビット回転数を最適ビット回転数 $N_{m}$ と 名ずける。最適ビット回転数は次式が与えられる。

最適ビット回転数

$$
\begin{aligned}
N_{m} & =\frac{D R_{b}}{m\left(W_{b}-W_{c}\right)} \\
& =\frac{4.2 D R_{b}}{m\left(W-W_{c}\right)}
\end{aligned}
$$

軟層用ビットを使用し，泥水循環の作用が不十分な状 態で掘さくするとすると，与えられたビット荷重を(10) 式の $W$ のところに代入し，与えられた衝撃力より求ま る $R_{b}$ を用いて, 最適ビット回転数が計算できる。中硬 層用や硬層用ビットでは作用線より分岐すると，相対掘 進率は軟層用ビットの時に比べて小さいので, 泥水循環 の作用が十分な範囲で使用した方がよいと思われる。こ のようなときは与えられたビット荷重を（9）式の $W_{b}$ のところに代入することにより, 最適ビット回転数が求 ままる。

以上記したことをまとめて簡単に第 1 図で説明する。 交点荷重 $W_{c}$ より引いた 2 本の実線は, それぞれビット 回転数 $N_{1}$ と $N_{2}\left(N_{1}>N_{2}\right)$ に対する作用線であり，(1) 式を表わしている。衝撃力 $M$ が与えられると(2)式よ り分岐点掘進率 $R_{b}$ が求まり, また $(7)$ 式より最大掘 進率 $R_{m}$ が求まる。 $R_{b}$ と $R_{m}$ はビット回転数に関係 なく等しい。各ビット回転数に対する分岐点掘進率 $W_{b 1}$ と $W_{b 2}$ は $(5)$ 式より, $R_{m}$ に対応するビット荷重 $W_{m 1}$ と $W_{m 2}$ は (8) 式より求まる。ビット回転数と $W_{b}$ および $W_{m}$ の間には（9）式あるいわ (10) 式が 
第 1 図ビット回転数の影響（衝撃力一定）

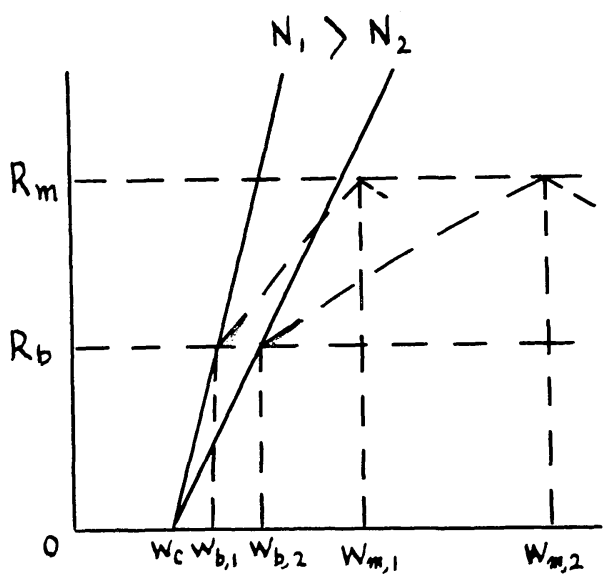

成立している。分岐点荷重以上のビット荷重に対する掘 進率は（6）式を用いて計算できる。

これまではビット回転数は任意の值を取りうるとした が，掘さく装置によってはビット回転数に最大限界值が あることがある。このようなときの掘進率を検討してみ る。

衝撃力 $M$ とビット荷重 $W$ が与えられ, ビット回転 数の最大限值 $N^{\prime}$ が定まっているとする。(9)式または (10) 式より求めた最適ビット回転数 $N_{m}$ が $N^{\prime}$ より大 きいとする。第 2 図にこの状態を示す。与えられたビッ 卜荷重 $W$ が $N^{\prime}$ に対する分岐点荷重 $W_{b}^{\prime}$ より小さけ れば，掘進率は $(1)$ 式で与えられ， $R_{b}$ より小さい。 $W>W_{b}^{\prime}$ では掘進率は $R_{b}$ と $R_{m}$ の間にある。この掘 進率を $R^{\prime}$ とすると，次の手順で計算できる。

(a) 衝撃力 $M$ より (2) 式で $R_{b}$ を求め，（5)式を 用いて分分岐点荷重 $W_{b}^{\prime}$ を求める。

（b）ビット荷重 $W$ と $W_{b^{\prime}}$ より相対荷重 $\left(W-W_{c}\right)$ $\left./ W_{b}^{\prime}-W_{c}\right)$ を計算する。

第 2 図ビット回転数に制限があるときの掘進率

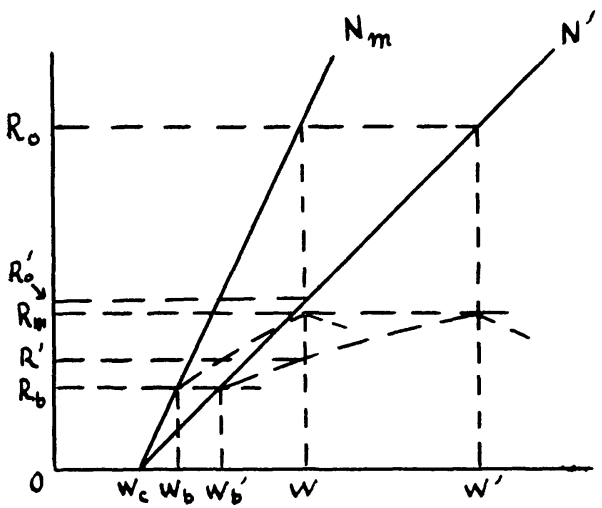

（c）ビット荷重 $W$ とビット回転数 $N^{\prime}$ より（1）式 を用いて，泥水循環の作用が十分と仮定したときの 掘進率 $R_{0}^{\prime}$ を求める。

(d) $\mathrm{b}$ で求めた $\left(W-W_{c}\right) /\left(W_{b^{\prime}}-W_{c}\right)$; $\mathrm{c}$ て求めた $R_{0}{ }^{\prime}$ を（5）式の相対掘進率の式に代入して，掘進 率 $R^{\prime}$ を計算する。

$$
R^{\prime}=R_{0}\left(\frac{13}{\frac{W_{b}-W_{c}}{W-W_{c}}+12}\right)^{3.85}
$$

以上記したように，泥水循環の作が不十分なところで は, 掘進率はビット荷重・ビット回転数・泥水循環の 3 つに関係して定まり，泥水循環の值を増加することによ り掘進率を增加することがきる。

\section{2. ビット使用時間とビット使用長さ}

ビッド寿命はビット全回転数で表わすことができる。 ビット全回転数は（4）式で表わされ，ビット荷重に関 係する。ビット使用時間はビット全回転数をビット回転 数で割って得られる。

ビット使用時間

$$
T=\frac{f}{N\left(D_{0} W / D\right)^{g}}
$$

ビット荷重 $W$ とビット回転数 $N$ を（1）式に代入 して得られる掘進率 $R_{0}$ をとすると，(11）式は次のよ うになる。

$$
T=\frac{f m}{D R_{0}} \frac{W-W_{c}}{\left(D_{0} W / D\right)^{g}}
$$

ある一定の掘進率で掘さくするとき，ビット使用時間 を最大にする条件は $g$ の值により異なる。 $g \leq 1$ のとき はビット荷重が大きい注どビット使用時間は長くなる。 $g>1$ のときは $W=(g / g-1) W_{c}, N=(g-1) D R_{0} / m W_{c}$ のときビット使用時間は最大になる。

ビット使用長さはビット使用時間と掘進率の積で与え られる。泥水循環の作用が十分で掘進率が作用線の式で 表わされるときは，次のようになる。

ビット使用長さ

$$
L_{0}=R_{0} T=\frac{f m}{D}-\frac{W-W_{c}}{\left(D_{0} W / D\right) g}
$$

掘進率が作用線より分岐した後では，ビット使用長さ Lとそのときのビット荷重を（13）式に代入して求めた $L_{0}$ との比は相対掘進率に等しい，すなわち， $L / L_{0}=R /$ $R_{0}$ 。

土崎沖油田および雲出ガス田の軟層用ビットの全回転 数は次式で与えられる（田中，1968-b)。

$$
N T=\frac{47 \times 10^{4}}{60 \times(21.6 / D)^{0}}
$$

$g=0.5$ であるから, 一定掘進率で掘さく市るときは, ビット荷重の大きい方が使用時間り使用長さも大きくな る。なお，掘進率一定であるからビット荷重を増加する 
と，ビット回転数を減少することが必要である。

ビット回䎐数に制限があり，最適ビット回転数以下で 掘さくするときは, 最適ビット回転数で掘さくするとき に比べて，掘進率は低下するが，使用洔間と使用長さは 増加する。

\section{II 特 性 曲 線}

ビット荷重はドリルカラーにより与えられる。したが って通常の掘さく作業では, ビット荷重とドリルカラー 本数とは此例すると考えてよい。ビットノズルで出しう る衝揧力もドリルカラーの長さ, すなわち本数により変 化する。したがってビット荷重と衝撃力は，ある一定の 関係で結ばれている。この関係は一般的に取扱うには複 雑すぎるので，具体的な例を用いて説明する。ドリルカ ラー本数と掘進率・ビット回転数・ビット使用長さ等と の関係を表わしたものを特性曲線と名ずける。特性曲線 はビット径・ドリルカラー寸法・掘管寸法ポンプ性能, 泥水の性質および地質などにより変わってくる。
第 3 図に特性曲線の例を示す。対泉にした地層は土崎 沖油田船川層中部である。ビットは $269.9 \mathrm{~mm}$ 径 $\left(10^{5} / 8\right.$ in) $3 \mathrm{~S}$ 及型, ポンプは $\mathrm{OH}-500$ (ライナー径 $63 / 4$ in), 掘管は $114.3 \mathrm{~mm}$ 外アプセット管, ドリルカラーは $177.8 \mathrm{~mm}$ 外径 $\times 71.4 \mathrm{~mm}$ 内径 $\times 164 \mathrm{~kg} / \mathrm{m}$ の $6 \mathrm{~m}$ ものとす る。泥水は比重 1.6 , 流量は $1.83 \mathrm{kl} / \mathrm{min}$ 以上とする。 樑度 $1,020 \mathrm{~m}$ として衝撃力を計算し，地質は同一なも のが続くとする。な拈ビット荷重は泥水中のドリルカラ 一の重さの $80 \%$ とする。

\section{1. 掘進 率}

第 3 図の上半分に掘進率とドリルカラー本数の関係を 示す。ビット回䎐数を（10）式の最適值にしたとき， 200，150，100 $\mathrm{rpm}$ の 3 種類の一定值に保ったときの各 掘進率を示す。ビットは軟層用なので, 掘進率は $(7)$ 式 の最大掘進率を用いた。ビットノズルは衝撃力を最大に するものを用いた。

ドリカラー本数を増加すると, ドリルカラー内の圧力 損失が増加し, 衝撃力は減少し, 分岐点掘進率も減少す

第 3 図特性 曲線の例

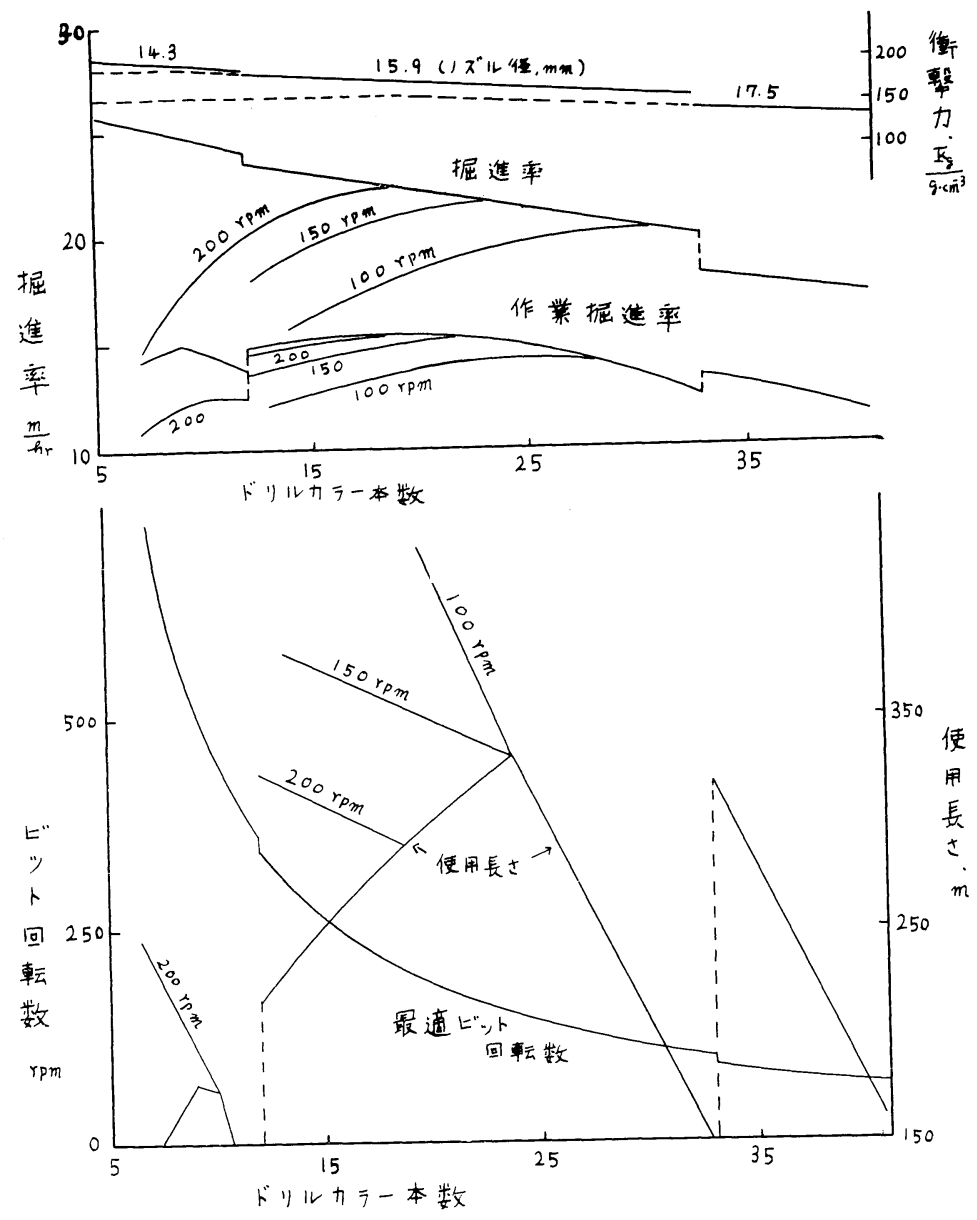


る。最適ビット回転数は第 3 図下半分に示すように, ビ ット荷重の増加と分岐点掘進率の減少により急激に減少 る。各ビット荷重に対する最適ビット、回転数で掘さくす るときの掘進率はビット荷重, すなわちドリルカー本数 の増加につれて减少する。

ビット回転数を一定に保ったときの掘進率を $200 \mathrm{rpm}$ のときを例に説明する。ドリルカラー本数10本のとき， 最適ビット回転数は $450 \mathrm{rpm}$ で，掘進率は $24.5 \mathrm{~m} / \mathrm{hr}$ である。ビット回転数を $100 \mathrm{rpm}$ に制限すると，掘進率 は $18.5 \mathrm{~m} / \mathrm{hr}$ に低下する。ドリルカラー本数を堌加す ると, 最適ビット回転数に対する掘進率は減少するが, $200 \mathrm{rpm}$ に保ったときの掘進率は增加する。ドリルカー 19本のとき最適ビット回転数は $200 \mathrm{rpm} に な り ，$ 雨者 の掘進率は一致する。これ以上ドリルカラーを増加する と，最適ビット回転数は $200 \mathrm{rpm}$ 以下になり，200 rpm に保つときの掘進率は，ふたたび最適值に対するそれよ り小さくなる。したがってビット回䎐数 $200 \mathrm{rpm}$ で掘

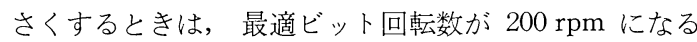
19本前後のドリルカラーを使用するとき, 掘進率は最も 大きくなる。同様に $150 \mathrm{rpm}$ のときはドリルカラー 23 本, $100 \mathrm{rpm}$ のときは 32 本前後で, 掘進率はもっとも大 きくなる。ビット回転数の制限值が大きいほど最適ドリ ルカラー本数は少なく, 掘進率は大きい。

第 3 図ではドリルカラー本数が増加すると衝撃力は減 少したが, あるドリルカラー本数間では衝撃力は一定で, 掘進率も一定になることもある。ビット荷重を増加する ほど掘進率は大きくなるといわれているが，上記のこと より，一般的には次のようにいうのが正しいと考える。

（1）ビット荷重ごとに掘進率が最大になる最適ビット 回䎐数がある。

（2）最適ビット回転数で掘さくするときは，ビット荷 重を増加するほど掘進率は低下する，ときにはある 範囲内で一定である。

（3）一定ビット回転数で掘さくするときは，この一定 值と最適值が一致するビット荷重で掘進率は最大に なる。この荷重に達するまでは, ビット荷重を増加 するほど掘進率は増加する。

\section{2. 使用長さ}

第 3 図下半分にビット当りの使用長さを示す。最適ビ ット回転数で掘さくするときは，ドリルカラーを増加す るほど使用長さは増加する。一定ビット回転数のときは ドリルカラーを増加するほど使用長さは減少する。同一 ドリルカラー本数では，ビット回転数が少ない流ど使用 長さは大きい。

ドリカラー本数が 24 本以上で使用長さは急激に減少し ている。これはポンプが限界に達したためである。ドリ
ルカラ 24 一本まではビットの使用可能長さの方が，ポン プの使用可能限界より短いので, ビットは十分に使用さ れてから引揚げられるが，24本以上ではポンプの使用限 界の方が短く，ビットがまだ余力を残しているとき，ポ ンプライナー取替またはビットノズル取替えのため引揚 げられねばならないことを亦している。

\section{3. 作業掘進率*}

掘進率と使用長さを一緒にまとめて考虑し, 掘さく作 業全体の進み方を表わしたものが作業掘進率であり，第 図 3 上半分の掘進率の下に示す。揚降管作業時間は, $3 \mathrm{hr} / 1000 \mathrm{~m}$ ，掘管継足し作業時間は $1 \mathrm{hr} / 100 \mathrm{~m}$ とし た。

最適ビット回䎐数で掘さくするとき, 掘進率はドリル カーの増加につれて減少するが，作業掘進率はドリルカ ラー18本で最大になる。一定ビット回漳数で掘さくする ときは,この一定值と最適值が一致するドリルカラー本 数で，すなわち掘進率が最大になるところで作業掘進率 む最大になる。100 rpm のときは掘進率が最大になる本 数と作業掘進率が最大になる本数と多少異なっている がこれはポンプの使用長さにおよぼす影響のためであ る。作業掘進率が最大になる条件を第 1 表に示す。

第 3 図を用いてタービン式掘さくとロータリ式掘さく の比較ができる。タービン式掘さくでは使用可能なノズ ル径は大きくなるが, 第 3 図のノズルを使用するとする。 タービン式掘さくではビット 回転数は $500 \mathrm{rpm}$ 位であ る。最適ビット回転数が $500 \mathrm{rpm}$ であるドリルカラー本 数は 9 本である。このときの掘進率は $24.7 \mathrm{~m} / \mathrm{hr}$ ，作業 掘進率は $14.9 \mathrm{~m} / \mathrm{hr}$, 使用長さは $70 \mathrm{~m}$ である。これら と第 1 表を比べると掘進率はタービン式の方がよいが， 作業掘進率は $100 \mathrm{rpm}$ を除きロータリ式の方が大きく， 使用長さもロータリ式の方がよい。したがってこの地層 では，150 rpm 位のビット回転数がだせるならば，ロー タリ式の方が適しているといえる。

第 1 表 作業掘進率が最大になる条件(第 3 図参照)

\begin{tabular}{|c|c|c|c|c|c|}
\hline $\begin{array}{l}\text { ビット } \\
\text { 回転数 } \\
\text { (rpm) }\end{array}$ & $\begin{array}{l}\text { ドリル } \\
\text { カララ } \\
\text { 本 数 }\end{array}$ & $\begin{array}{l}\text { ビット } \\
\text { 荷 } \\
\text { (t) }\end{array}$ & $\begin{array}{l}\text { 掘進率 } \\
(\mathrm{m} / \mathrm{hr})\end{array}$ & $\begin{array}{l}\text { 作 業 } \\
\text { 掘進率 } \\
(\mathrm{m} / \mathrm{hr})\end{array}$ & $\begin{array}{l}\text { 使 用 } \\
\text { 長 } \\
\text { (m) }\end{array}$ \\
\hline 220 & 18 & 11.3 & 22.7 & 15.4 & 330 \\
\hline 200 & 19 & 11.8 & 22.3 & 15.3 & 350 \\
\hline 150 & 23 & 14.4 & 21.6 & 15.2 & 460 \\
\hline 100 & 25 & 15.6 & 19. 7 & 14.2 & 400 \\
\hline
\end{tabular}

* ソ連邦における堀進率の研究（田中, 1964, 石技誌) で, 航海掘進 率として紹介したものである。 


\section{III 掘さく作業計画の例}

雲出ガス田西山層上部を対象に掘さく作業計画のたて 方を検討する。ビット $31.1 \mathrm{~cm}$ 径 $3 \mathrm{~S}\left(12^{1} / 4 \mathrm{in}\right)$, ドリ ルカラー $203.2 \mathrm{~mm}(8 \mathrm{in}) \times 71.4 \mathrm{~mm}\left(2^{13} / 16\right) \times 224 \mathrm{~kg} / \mathrm{m}$ $9 \mathrm{~m}$ 管, 掘管 $127 \mathrm{~mm}(5 \mathrm{in}) \times 27.2 \mathrm{~kg} / \mathrm{m}(19.5 \mathrm{lb} / \mathrm{ft}) 9$ $\mathrm{m}$ 管, 泥水比重 1.4 とし, 深度は $1,400 \mathrm{~m}$ とする。ポ ンプは H-850 A 1 台または 2 台並列運転とし, 機械効 率 $85 \%$, 容積效率 $90 \%$ とする。ビット荷重はドリルカ ラ一の泥水中の重量の $80 \%$ とする。作用線の式と分岐 点掘進率の式を次に記す（田中，1968-b)。

$$
\begin{array}{ll}
\text { 作用線の式 } & R_{0}=N(W-0.9) / 37.3 \\
\text { 分岐点掘進率の式 } & R_{b}=3.6+0.034 M
\end{array}
$$

\section{1. ポンプ 1 台と 2 台との比較}

ドリルカラー本数は15本，ビット荷重は $19.8 \mathrm{t}$ とす る。ノズルは $15.9 \mathrm{~mm}$ 径 $(5 / 8$ in) を 3 ケ使用すか。ポ ンプ 1 台のときと 2 台並列のときの諸数值の比較を第 2 表に示す。分岐点掘進率は (b) 式に第 2 表の衝撃力を代 入して求めた。最適ビット回転数は(10)式で $W=19.8$, $W_{c}=0.9, R_{b}$ に第 2 表の分岐点掘進率を代入して求めた。 最大掘進率は ( 7 ) 式より求めた。第 2 表をグラフに示 したのが第 4 図である。(a) 式より求めたビット 回転数
第 2 表 ポンプ数の影響（計画）

\begin{tabular}{|l|c|c|c|}
\hline ポン プ 数 & 1 & 2 & 比 率* \\
\hline ライナー径, in & $71 / 2$ & 6 & \\
流量, $\mathrm{k} l / \mathrm{min}$ & 2.34 & 3.06 & 1.3 \\
衝撃力, $\mathrm{kg} / \mathrm{g} \cdot \mathrm{cm}^{-3}$ & 260 & 440 & 1.7 \\
分岐点掘進率, $\mathrm{m} / \mathrm{hr}$ & 12.4 & 18.6 & 1.5 \\
最適ビット 回転数, $\mathrm{rpm}$ & 103 & 154 & 1.5 \\
最大掘進率, $\mathrm{m} / \mathrm{hr}$ & 23 & 35 & 1.5 \\
\hline
\end{tabular}

* ポンプ数 1 のときを 1.0 とする。

$150 \mathrm{rpm}$ と $100 \mathrm{rpm}$ のときの作用線を実線で示す。横 軸に平行に引いた破線は, ポンプ 1 台のときと 2 台のと きの分岐点掘進率を示す。

ビット回䎐数が $100 \mathrm{rpm} の$ 場合, ポンプ 1 台のときは ビット荷重 $5.5 \mathrm{t}$ で分岐点に達し, それ以後は掘進率は 破線 (1) に沿って増加し，ドリルカラー15本に相当する ビット荷重 $19.8 \mathrm{t}$ で掘進率は最大值 $23 \mathrm{~m} / \mathrm{hr}$ に達する。 途中の破線は ( 6 ) 式の相対掘進率の式を用いて求めた。 ポンプ 2 台並列運転のときはビツト荷重 $7.8 \mathrm{t}$ で分岐点 に達し, それ以後は破線 (2) に沿って掘進率は增加し, $19.8 \mathrm{t}$ で掘進率は $31 \mathrm{~m} / \mathrm{hr}$ である。この場合ビット荷 重 $30 \mathrm{t}$ で最大掘進率 $35 \mathrm{~m} / \mathrm{hr}$ になる。ポンプを 1 台よ

第 4 図 ポンプ台数の影響（計画）

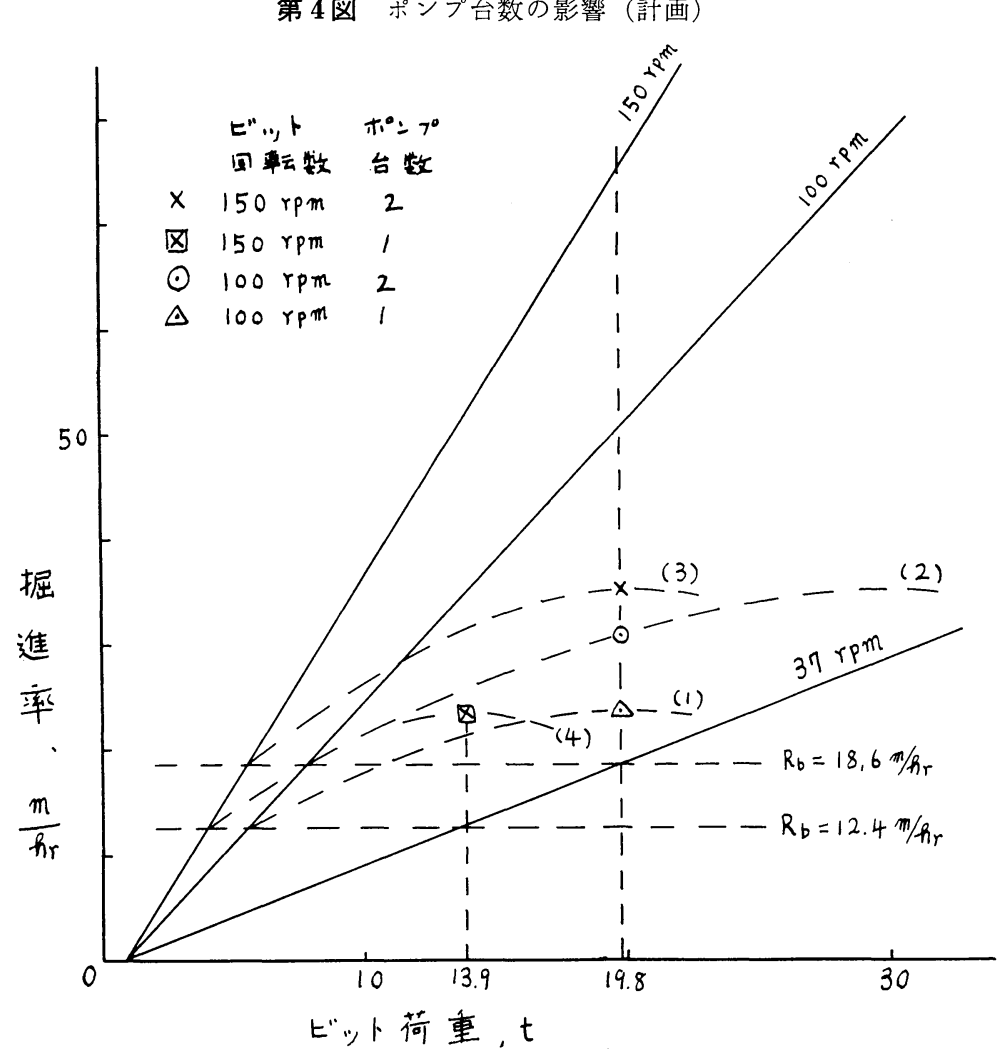


り 2 台にすることにより，ビット回転数 $100 \mathrm{rpm}$, ビッ 卜荷重 $19.8 \mathrm{t}$ で掘進率は $23 \mathrm{~m} / \mathrm{hr}$ から $31 \mathrm{~m} / \mathrm{hr}$ に 1.3 倍増加する。

ビット回転数 $150 \mathrm{rpm}$ の場合。ポンプ 2 台使用すると きはビット荷重 $5.5 \mathrm{t}$ で分岐点に達し, それ以後は破線 (3)に沿って掘進率は増加し, $19.8 \mathrm{t}$ で $35 \mathrm{~m} / \mathrm{hr}$ の最大 值に達する。ポンプ 1 台のときはビット荷重 $4 \mathrm{t}$ で分岐 点に達し, それ以後は破線(4)に沿って掘進率は増加し, ビット荷重 $13.9 \mathrm{t}$ で最大值 $23 \mathrm{~m} / \mathrm{hr}$ に達し, それ以上 ビット荷重を増加すると, かえって掘進率は減少する。 ポンプ1台で $150 \mathrm{rpm}$ のときは $13.9 \mathrm{t}$ 以上のビット荷 重はかけられない。

ここで設定した条件では，ポンプ1台のときはビット 回䎐数 $100 \mathrm{rpm}$ て $23 \mathrm{~m} / \mathrm{hr}$ の掘進率，ポンプ 2 台のと きは $150 \mathrm{rpm}$ で $35 \mathrm{~m} / \mathrm{hr}$ の掘進率が見込まれ，ポンプ を 1 台より 2 台にすることにより，掘進率は 1.5 倍増加 する。

ビット使用長さは (11)式，(13)式，(14)式より $L \propto$ $R / N W^{0.5}$ となる。ビット荷重は一定とすると $L \propto R / N$ である。 $R / N$ を求めると, ポンプ 1 台 $100 \mathrm{rpm}$ のとき 0.23 ，ポンプ 2 台 $100 \mathrm{rpm}$ のとき 0.31 ， ポンプ 2 台 $150 \mathrm{rpm}$ のとき 0.23 である。これより, 掘進率が最も 大きくなる組み合わせは, ポンプ 2 台でビット回転数
$150 \mathrm{rpm}$ のとき，ビット使用長さが最も大きくなる組み 合わせは，ポンプ 2 台でビット回転数 $100 \mathrm{rpm}$ のとき であう。

ポンプ 2 台並列運転のとき，ビット荷重 $19.8 \mathrm{t}$ で泥 大循環の作用が十分な状態で掘さくするとすると，その 条件での最大の掘進率は分岐点掘進率と等しく $18.6 \mathrm{~m}$ /hr である。このときのビット回䎐数は（9）式より $37 \mathrm{rpm}$ である。これを第 4 図に $37 \mathrm{rpm}$ と付した作用 線で表わす。泥水循環の作用が不十分な状態ではビット 回䎐数を増加すると，ある限度までは掘進率は増加する が，その増加の割合は小さい。第 4 図では $37 \mathrm{rpm}$ で掘 進率 $18.6 \mathrm{~m} / \mathrm{hr}, 150 \mathrm{rpm}$ で $35 \mathrm{~m} / \mathrm{hr}$ であるから，ビ ット回転数を 4 倍して掘進率は 1.9 倍になる。ポンプ 1 台のとき, ビット回䎐数 $100 \mathrm{rpm}$ で掘進率は $23 \mathrm{~m} / \mathrm{hr}$ である。ポンプ 2 台では，50～60 rpm 位でこれ位の掘 進率になる。

ポンプを 1 台より 2 台に増加することにより得られる 効果は，次のようにまとめられる。

（1）最適ビット回転数が増加し, 掘進率の増加が得ら れる。

（2）同一ビット回転数で掘さくするとき，掘進率が増 加し, 掘進長さを増加する。

(3) 同一掘進率が小さいビット回転数で得られ, 掘進

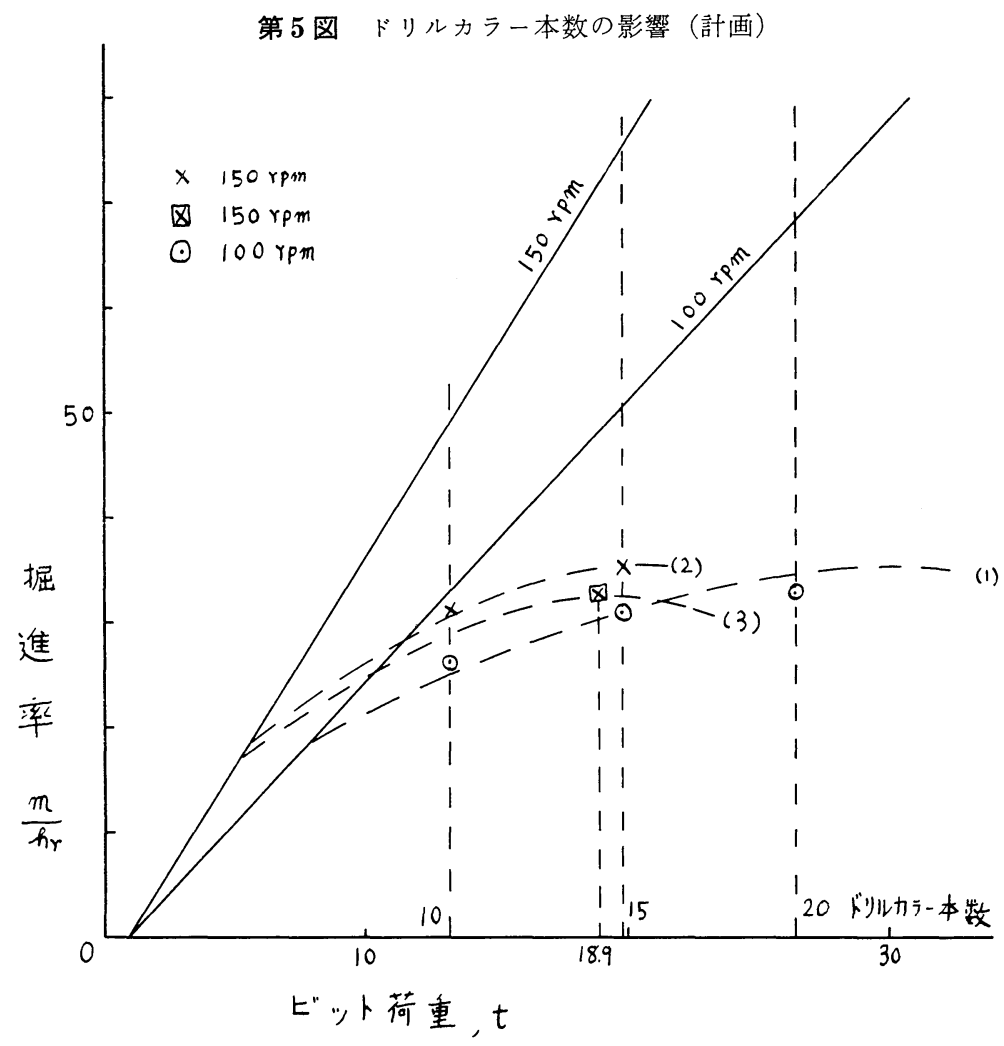


長さが増加する。

\section{2. ドリルカラー本数の影響}

前と同じ条件でポンプは 2 台並列運䎐とし，ドリルカ ラーを 10 本（ビット荷重 $13.2 \mathrm{t}$ )，15 本（ビット荷重 $19.8 \mathrm{t}), 20$ 本（ビット荷重 $26.4 \mathrm{t}$ ）と変えたときの掘進 率の変化を第 5 図に示す。 $15.9 \mathrm{~mm}$ ノズルを使用する ときの各本数に対する流量はそれぞれ $3.10 \mathrm{kl} / \mathrm{min}$, $3.06 \mathrm{kl} / \mathrm{min}, 2.92 \mathrm{kl} / \mathrm{min}$ である。ビット回転数は $150 \mathrm{rpm}$ と $100 \mathrm{rpm} の 2$ 種類とし，それぞれに対する 作用線を第 5 図に実線で示す。ドリルカラー15本のとき の分岐後の掘進率の変化を破線 (1)，(2) で示す。

ビット回䎐数 $100 \mathrm{rpm}$ のときの各ビット荷重に刘す る掘進率はそれぞれ $26 \mathrm{~m} / \mathrm{hr}, 31 \mathrm{~m} / \mathrm{hr}, 33 \mathrm{~m} / \mathrm{hr}$ であ る。ビット回転数 $150 \mathrm{rpm}$ のときのドリルカラー 10 本 に対する掘進率は $31 \mathrm{~m} / \mathrm{hr}, 15$ 本に対す万掘進率は 35 $\mathrm{m} / \mathrm{hr}$ である。ドリルカラー20本のときは破線(3)で示す 変化をし, ビット荷重 $18.9 \mathrm{t}$ で最大值 $33 \mathrm{~m} / \mathrm{hr}$ に達す る。掘進長さに比例するものとして $R / N W^{0.5}$ を, 掘さ く馬力に比例するものとして $N W^{2}$ を計算し第 3 表に示 す*。

第 3 表より，掘進率の大きいものがかならずしも掘さ く馬力が大きくなく，傾向としてビット荷重が小さく， ビット回転数の大きい方が掘さく馬力に比して掘進率が 大きい。掘進長さはビット回䎐数の小さい方が大きい。 これらより判断すると，第 3 表の No. 1，3，4 の組み 合わせのうちより，選択するのがよいと考えられる。

第 3 表 ドリルカラー本数の影響（計画）

\begin{tabular}{|c|c|c|c|c|c|c|}
\hline No. & $\mid \begin{array}{lll}ト ゙ & リ & \\
\text { カ } & \text { ラ } \\
\text { 本 } & \text { 数 }\end{array}$ & $\begin{array}{l}\text { ビット } \\
\text { 回転数 } \\
\text { rpm }\end{array}$ & $\begin{array}{l}\text { 掘進率 } \\
\mathrm{m} / \mathrm{hr}\end{array}$ & $\mid \begin{array}{l}\text { 掘進率 } \\
\text { 比 } \quad \text { 率 }\end{array}$ & $\begin{array}{c}\text { 掘集長さ } \\
\mathrm{R} / \mathrm{NW}^{0.5} \\
\times 10^{2}\end{array}$ & $\begin{array}{l}\text { 掘さく } \\
\text { 馬 } \\
\mathrm{NW}^{2} \\
\times 10^{-4}\end{array}$ \\
\hline 1 & 15 & 150 & 35 & 1. 35 & 5.2 & 5.9 \\
\hline 2 & 20 & 100 & 32 & 1. 27 & 6.4 & 7.0 \\
\hline 3 & 10 & 150 & 31 & 1. 2 & 5.7 & 2.6 \\
\hline 4 & 15 & 100 & 31 & 1. 2 & 7.0 & 3.9 \\
\hline 5 & 10 & 100 & 26 & 1.0 & 7.2 & 1.7 \\
\hline
\end{tabular}

* Maurer は泥水循環の作用が十分なときはビットトルクはW 2 に, 不十分なときは $W 1.5$ に比例するとしている(Jour. Pet. Tech., nov., 1962).

\section{VI 結 語}

室内実験および現場記録の解析により得られた諸式を 一般化して, 泥水循環の作用が十分なときおよび不十分 なときのそれぞれの条件下に打いて，掘進率・最適ビッ ト回祘数・ビットの使用時間・ビットの使用長さ等を求 める才j法を論じた。

一般論の応用として，ドリルカラー本数と前記各指数 との関係を表わす特性曲線について説眀した。最適ビッ 卜回転数で掘さくするときは, ビット荷重の堌加につれ て一般には掘進率は減少する。ビット回転数一定で掘さ くするときは，この一定值と最適值が一致するビット荷 重までは，ビット荷重を增加するにつれ掘進率は增加す る。坑井が深くなる速度を表わす作業掘進率は, ビット 回䎐数一定で掘さくするときには, この一定值と最適值 が一致するビット荷重で最大になる。

また掘さく作業計画の 1 例として，31. cm (12 $1 / 4 \mathrm{in})$ 径 ビットで掘さくするときの，ポンプ台数の影響とドリル カラー本数の影響を考察した。

\section{参 考 文 献}

1) Edwards J.H.1964; Engineered Drilling Operations: W.O., May, pp. 87-92 and June, pp. 120-125.

2) Galle E.M. and Woods H.B., 1963, Best Constant Weight and Rotary Speed for Rotary Rock Bits : Spring Meeting of the Pacific Coast District Division of Production, API.

3）田中彰一，1968，a，ロータリ一掘さくの掘進率 におよぼす泥水循環の作用に関する研究：石技誌 第33巻第 3 号, pp. 169-174.

4) 田中彰一，1968，b，土崎沖油田执よび雲出ガス 田における掘進率と泥水循環の関係：石技誌，第 33 巻第 5 号, pp. 326-334. 